\title{
GEOCHEMICAL ASSESSMENT OF ARCHAEOLOGICAL SOILS FROM THE MONASTIC SITE OF NIKASALA NUWARA, KURUNEGALA, SRI LANKA
}

\author{
SANSFICA M. YOUNG ${ }^{1}$, D. T. MENDIS ${ }^{2}$, C. R. WITHANACHCHI ${ }^{2}$, H. ISHIGA ${ }^{3}$ \\ ${ }^{1}$ Department of Environmental Technology, Faculty of Technology, University of Colombo \\ ${ }^{2}$ Department of Archaeology and Heritage Management, Rajarata University of Sri Lanka \\ ${ }^{3}$ Department of Geosciences, Shimane University, 690-8504, Matsue, Japan \\ *Corresponding author e-mail: sansfica@et.cmb.ac.lk
}

(Received $6^{\text {th }}$ August 2019; accepted $28^{\text {th }}$ September 2019)

\begin{abstract}
Microarchaeological remain analysis is a rare approach in Sri Lankan archaeology. X-Ray Fluorescence analysis was used to identify geochemical properties of soil units recorded in archaeological excavations. Identifying range of elements through a stratigraphical sequence could reveal cultural activities and site formation processes. Proposed method was used for analyzing the soil recovered from an archaeological excavation at NikasalaNuwara Buddhist monastic complex. The excavated site was dated to 2-3 cent. A.D based on artifact classification. Stratigraphic sequence is undisturbed and four layers were reported. Low Fe concentration and higher $\mathrm{P}$ in the upper layer indicates reduced cultural activities and higher intensity of human activities. Arsenic, $\mathrm{Zn}, \mathrm{Cu}, \mathrm{Ni}, \mathrm{Cr}$ are low at the layer one and four while they are high at the layer two and three indicating increased cultural activities in layer two and three. Ti, $\mathrm{Sr}, \mathrm{Nb}, \mathrm{Zr}$ and $\mathrm{P}_{2} \mathrm{O}_{5}$ increased in the layers one and two while $\mathrm{MnO}$ and $\mathrm{Pb}$ shows no much variation which could relate to oxidizing conditions of soils. Vanadium shows high variation throughout the profile. As it was apparent from the results, the chemical composition of the site is highly shaped by the cultural process rather than natural factors.
\end{abstract}

Keywords: Microarchaeological remains, Soil, Elements, Layer, Human Activities

\section{INTRODUCTION}

An interdisciplinary approach and techniques in archaeology borrowed from the fields of physics, geography, chemistry, geology and geochemistry have been widely applied to reslove archaeological problems such as finding chemical composition of artifacts and biophysical matrix in which those artifacts were recovered (Hughes et al., 1993). In geochemical studies in the past, provenance studies have been carried out to determine the sources of raw materials of tools used by prehistoric human (Hughes et al., 1993; Selivanova et al., 1998). Reconstructing the ancient trade, settlement patterns, technological changes or subsistence strategies and palaeo-demography has become more feasible with the application of new geochemical analytical methods. 
The archaeological record is continuously changing by the formation processes and some of the material remains are decaying with time. Therefore, in such areas, interpretations are difficult to made using artifact data alone, and soil chemical data provide important evidence of the ancient human activities. In addition, human settlement activities are connected with the accumulation of nutrients in archaeological soils (Holliday and Gartner 2007; Vranová et al., 2015; Smejda et al., 2017; Strimaitienè et al., 2017). Therefore, "soil chemical analysis" is one of the powerful archaeological tools that can help researchers to understand the spatial usage patterns by allowing specific activity areas to be examined (Dalai, 2012). Nevertheless, irregular concentrations of elements always are not in relation with anthropogenic activities, and natural processes primarily influence the total geochemical composition of soils (Middleton et al., 1996; Wilson et al., 2008). However, various geological processes that have taken place during and after site occupation are complex and not yet fully understood (Dalai, 2012).

Specific chemical fingerprints have been left by the human activities in the soils. As a result, the chemical elements are retained fully or partially in the soils. Anthropogenic inputs of several historical eras may include metal slags, pottery, beads, tiles and burials. Consequently habitation can lead to enrichment and depletion of certain elements in the archaeological soils compared to unoccupied spaces.

The chemistry of archaeological soils is often studied to either locate or delineate archaeological sites and human activity areas (Bintliff et al., 1990; Aston et al., 1998; Schlezinger et al., 2000; Linderholm, 2007), or to elucidate functions of subareas within archaeological sites as different land types and soil features (Entwistle et al., 1998; Wilson et al., 2008; Emadodin, 2011). The recent and past anthropogenic inputs can change the geochemical composition of archaeological soils. These complexities in archaeological soils need to be differentiated between recent and past archaeological signals in soils. The elements of concern and their variation levels should be considered as indications of archaeological impacts (Dalai, 2012). The artifacts, soil stratigraphic sequence and geological features give good evidence of the activities, and the processes that has taken place within the area. Thus, geochemical data in combination with archeological findings provides better understanding in historical events. Finally, this leads to accurate prediction of historical activities.

The objective of the present study is to identify the ancient cultural activities of the studying site using archaeological evidence and enhance the findings incorporating geochemical data of surface soils and soil of the stratigraphic sequence of the study area.

\section{STUDY AREA}

Nikasala Nuwara is located in Kurunegala District of Sri Lanka (Fig. 1). Climatically the region is in the intermediate zone. Study area is located in the Kolomunu Oya sub-basin of the Deduru Oya basin. The soil type of the area is red yellow podzolic (RYP) soils. The erodibility of a RYP soil is 'well' to 'imperfectly drained'with the erodibility value of 0.29 and the soil depth is usually 'moderately deep' to 'deep' (Conservation of Soil Resources, 2016). Nikasala Nuwara is surrounded by the Madagama Mountain range, which has a rich biodiversity. A continuous archaeological record from 3rd century BC to the Polonnaruwa period had been reported from the study area. The major archaeological remain is the Buddhist monastic site (Nikasala Nuwara Rajamaha Viharaya). Since the 7th century AD, Nikasala Nuwara was developed as a settlement in the hinterland of the regional capital Panduwas Nuwara. Activities such as iron smelting could be observed from the archaeological records during this period. Several furnaces of ca. $50 \mathrm{~cm}$ length dated to the 12th century $\mathrm{AD}$ have been discovered from the study area. A terrace, built with rock and bricks, found in the area is believed to be built to prevent the erosion. 


\section{Previous Investigations}

The middle Daduru Oya basin is in the northwestern region. Sri Lanka was first colonized by the hunter - gatherers during the Mesolithic period. After several decades, in 1970 's several rock shelters with stone artifacts were discovered (Deraniyagala, 1992). Between 2010- 2013 a Mesolithic period rock shelter in the Yapahuwa Fort (Through communications) has been identified in this area. As per data from over the past two decades of Archaeological investigation, it is now suggested that the microlithic period was formally superseded by the proto historic Iron age in the study area. A review of the previous, proto-historic investigation undertaken by several scholars as Senevirathne (1984) and Department of Archaeology, Sri Lanka in 2003 indicated that approximately 10 proto historic Iron Age Megalithic burials and Porto-historic Iron Age settlement with the evidence of black and red ware pottery are located in the Daduru Oya basin. The Earliest known proto historic Iron Age settlement of North Western Province is reported from Polpithigama. At the Proto Historic Iron age was dated to be around 520 BC by radiocarbon dating (Unpublished, Personal communication with researches). According to another research on Andarawewa megalithic burial site by Mendis et al. (2019), and the dating has been recorded as 500 B.C which gives a similar dating.

\section{Archaeological Excavation}

The Department of Archaeology and Heritage Management, Rajarata University of Sri Lanka (RUSL) and The Central Cultural Fund (CCF) carried out a research at Nikasalanuwara, Mid-Daduru Oya basin, Sri Lanka from 2014 to 2016. The Mid-Daduru Oya basin was a cultural river basin in the Pre, Proto, Early and Historical period. Pre and Proto historic people had been settled in these river basins before the 6th century B.C, which has been confirmed according to the archaeological evidences. For the last ten years researchers had carried out some research and they have identified various types of settlements, burials, monasteries and their material culture in the Mid-Daduru Oya Basin (Seneviratne, 1984).

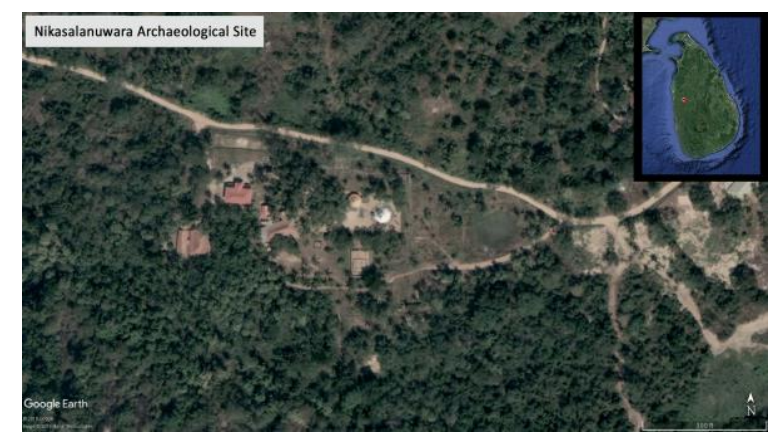

Fig. 1. The map showing the location and the excavated area.

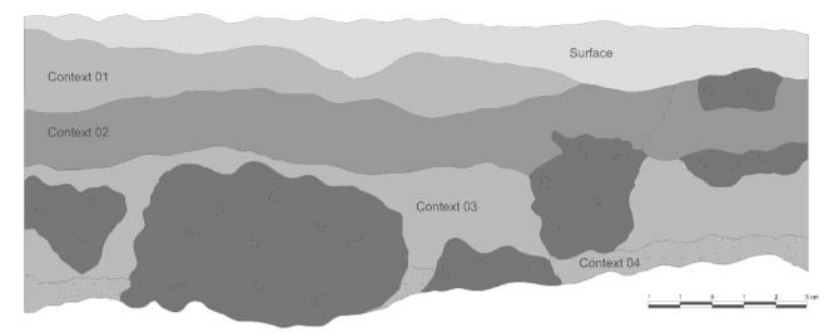

Fig. 2. Layers of the soil profile in the Nikasala Nuwara archaeological site showing the four Layers.

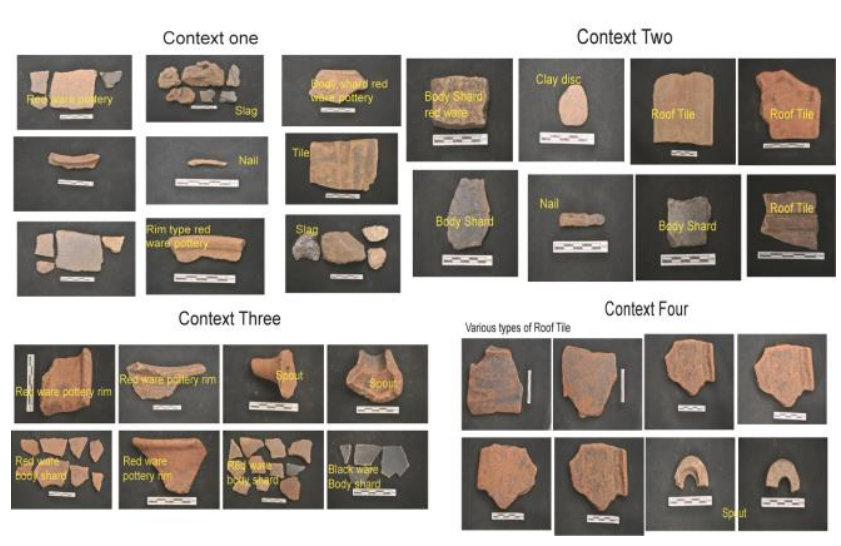

Fig. 3. The artifacts found in the layers one, two, three and four.

\section{METHODOLOGY}

\section{Archaeological Excavation}

The Nikasalanuwara Monastery complex (Fig. 1) was selected as the research area due to its archaeological value. A surface survey was designed to explore the inside and peripheral 
area of the monastery. A selected location was excavated (Fig. 1) using the vertical excavation method and context system.

Archaeologists must carefully document the associations and stratigraphic relationships between finds, soil deposits, architectural remains and other features as such associations are disrupted and destroyed through excavation. Archaeologists use the term "context" when they refer to such associations, and contextual information is critical in documentation and interpretation (Hodder et al., 2003). The potteries were assigned to a typology by its ware type.

\section{Geochemical Analysis}

Spatially distributed surface samples $(\mathrm{n}=10)$ and samples of a vertical profile $(n=13)$ were collected from the site and for these soils 22 elements were analyzed using $\mathrm{X}$-ray florescence spectrometry (XRF) method. The samples were collected at a depth of $6 \mathrm{~cm}$ into a labeled plastic bag and was sealed and transported to the laboratory in Japan.

The soil samples were oven dried at $120^{\circ} \mathrm{C}$ for 24 hours prior to geochemical analysis at Shimane University. Samples were first handsieved to remove the small amount of material $>2000 \mu \mathrm{m}$. The $<2000 \mu \mathrm{m}$ fraction was then split to obtain a sample for bulk soil analysis. Approximately $50 \mathrm{~g}$ of each soil sample were oven-dried at $160^{\circ} \mathrm{C}$ for $48 \mathrm{hrs}$ before crushing. All samples were powdered using an agate piston and mold for 20 minutes. The powdered soil samples were compressed into briquettes, using a force of $200 \mathrm{KN}$ for 60 seconds. The concentrations of 22 major and trace elements were then determined by XRF using a Rigaku RIX-2000 spectrometer equipped with a Rhanode tube. Analytical methods, instrumental conditions, and calibration followed those described by Ogasawara (1987). The pressed powder analysis followed Ogasawara (1987), using conventional peak over background (Ip/Ib) method, with calibration against recommended or preferred values for seven Geological Survey
Japan (GSJ) rock standards. Arsenic values were also corrected for $\mathrm{Pb}$ peak overlap. Average 2sigma coefficients of variation for the three elements range from $3.5-6.7 \%$ relative at concentrations of $>5 \mathrm{ppm}$. This was confirmed by repeat analysis $(n=5)$ of seven samples from this study, yielding similar results.

\section{RESULTS}

\section{Archaeological Excavation}

The excavation pit contains up to $105 \mathrm{~cm}$ of sediment fill. This was resolved into 16 contexts in 4 layers. The soils of the site indicate high human activities derived based on natural and cultural context readings. The surface layer contained humus, ruble fills and construction material. The four layers lying beneath consist of cultural materials including clay objects such as pottery, red ware, painted black ware, black ware, and tile such as flat tiles, clay disc, as well as metal objects such as nails, iron furnace and slags (Fig. 1). Among the layers, the layer 2 (Fig. 2) is highly significant which provided the evidences of iron smelting furnaces, iron slag and charcoal.

Mainly potsherds reported during the excavation and these were found from the first layer to the fourth layer. Typology of the potsherds consists of black ware, red-painted ware, red polished ware, black polished ware and black and red ware has been found (Fig. 3).

\section{Geochemical Analysis}

The elemental concentrations of the surface samples and the soil profile samples showed not much varation (Mean values in Table 1). Almost all the soil samples of the surface samples and the profile samples are well within or below Upper Continental Crustal (UCC) values (Table 1). However, the soil profile shows variations for each element (Figs. 4 and 5).

In the profile samples $\mathrm{As}, \mathrm{Zn}, \mathrm{Cu}, \mathrm{Ni}, \mathrm{Cr}$ concentrations are low at the surface and bottom and high at the middle part in the profile (Fig. 
4). Fe concentration is low at the surface but gradually increased towards the bottom (Fig. 5). Titanium, $\mathrm{Sr}, \mathrm{Nb}, \mathrm{Zr}$ and $\mathrm{P}_{2} \mathrm{O}_{5}$ concentrations are increased towards the surface while $\mathrm{MnO}$ and $\mathrm{Pb}$ show no variation and $\mathrm{V}$ shows a high variation throughout the profile (Fig. 5).

\section{DISCUSSION}

The mean values of $\mathrm{As}, \mathrm{Pd}, \mathrm{Zn}, \mathrm{Cu}, \mathrm{V}, \mathrm{Y}$, $\mathrm{Zb}, \quad \mathrm{Zr}, \quad \mathrm{Br}, \quad \mathrm{I}, \quad \mathrm{TiO}_{2}, \quad \mathrm{Fe}_{2} \mathrm{O}_{3}$ and $\mathrm{MnO}$ concentrations are higher than that of Upper Continental Crustal (UCC) values (Table 1) while the concentrations of other elements such as $\mathrm{Ni}, \mathrm{Cr}, \mathrm{Sr}$, Th, Sc, F, $\mathrm{CaO}$ and $\mathrm{P}_{2} \mathrm{O}_{5}$ are lower than that of UCC in both surface and profile samples. This indicates that there have not been any vast changes in human cultural activities since ancient times to recent past.

\section{Archaeological Excavation}

The four layers of the site provide a continues archaeological record. The pottery typology is ranging from the proto-historic black and red ware complex to the later historic red ware types. An increasing human input can be seen from the second layer with the iron smelting activities. The slags, consisted of limonite, jeotite and hematite are believed to be used in iron smelting (Fig. 3). The roof tiles and nails (Fig. 3) suggest a semi-permanent or a permanent structure in the site with wattle and daub walls or an open structure as no bricks or brick bats being reported. Though the study site is presently associated with a Buddhist monastic complex, the provenance of the potteries indicates a wide range of activities. As there are evidences of socio-technical activities such as iron smelting, it is better to conclude the temporal and spatial range and usage of the site may have been shifted between religious and economic activities.

\section{Variation in the Profile}

The surface soil samples and the profile soil mean elemental values are almost similar to each other (Table 1). In both surface soil samples and the profile soils $\mathrm{Ni}, \mathrm{Cr}, \mathrm{Sr}, \mathrm{Sc}, \mathrm{F}$, $\mathrm{CaO}$ and $\mathrm{P}_{2} \mathrm{O}_{5}$ concentrations are lower than Upper Continental Crustal (UCC) values (Table 1). Elements such as $\mathrm{As}, \mathrm{Pb}, \mathrm{Zn}, \mathrm{Cu}, \mathrm{V}, \mathrm{Y}, \mathrm{Nb}$, $\mathrm{Zr}$, Th, $\mathrm{Br}, \mathrm{I}, \mathrm{Cl}, \mathrm{TiO}_{2}, \mathrm{Fe}_{2} \mathrm{O}_{3}$ and $\mathrm{MnO}$ are higher than UCC values in both surface soil samples and the profile soils (Table 1).

Two horizontal layers, which showed anomalous values for many of the elements indicate an environmental change within the profile (Figs. 4 and 5). The vertical soil profile shows some interesting features, especially, for mafic elements such as $\mathrm{Fe}, \mathrm{Ti}, \mathrm{Cu}, \mathrm{Ni}$ (Fig. 4). The increased $\mathrm{Fe}$ concentrations from surface to the bottom of the soil profile may be related to reduced soil conditions while steady decrease of Ti may due to the grain size variation of the soil (Fig. 4). The other major oxides $\mathrm{Mn}, \mathrm{Ca}$ and $\mathrm{P}$ show a slight increase towards the surface of the soil profile (Fig. 5).

The horizon at 20-35 cm (Layer 2) has high values of $\mathrm{Fe}$ and $\mathrm{V}$. The horizon at $35-50 \mathrm{~cm}$ (Layer 2 and 3) has high values of $\mathrm{As}, \mathrm{Pb}, \mathrm{Zn}$, $\mathrm{Cu}, \mathrm{Ni}$ and $\mathrm{Cr}$. The horizon at 75-85 $\mathrm{cm}$ (Layer 4) has high values for $\mathrm{Pb}, \mathrm{Cu}, \mathrm{Cr}, \mathrm{V}$ and $\mathrm{Fe}$. These may relate to slag, furnace (paddy husk, sand and clay with termite clay) and $\mathrm{Fe}$ and $\mathrm{Cu}$ smelting during this period. Hematite and limonite are the raw materials used to prepare $\mathrm{Fe}$ or $\mathrm{Cu}$ and are brought from other areas. The nails may be from the buildings that were used for wooden works. No evidances were found on any metal ware manufacturing in this location. Further dating and detailed studies of the entire area should be done for better understanding of the archeological features and geochemical relationships. 


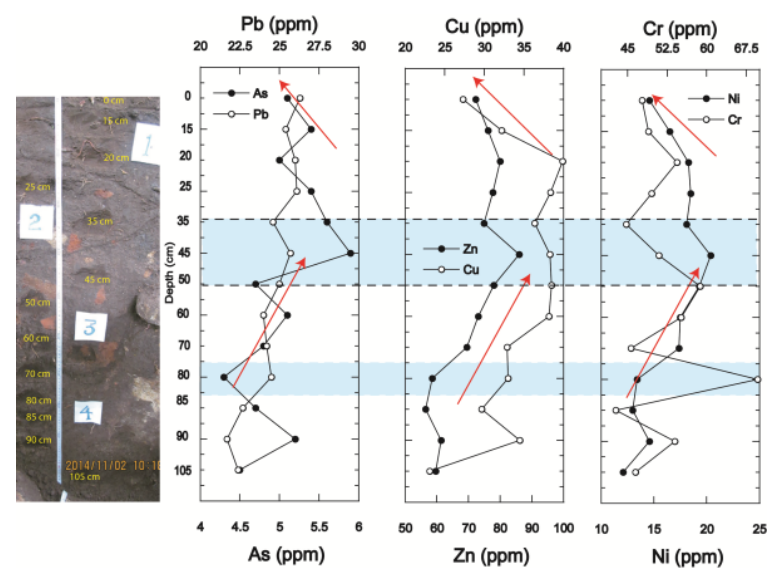

Fig. 4. Elemental variation of the soil profile at the Nikasala Nuwara archaeological site for $\mathrm{Cu}$ $\mathrm{Pb}, \mathrm{Zr}, \mathrm{Cr}, \mathrm{Zn}, \mathrm{As}$ and $\mathrm{Ni}$ with the corresponding soil profile and the layer numbers.

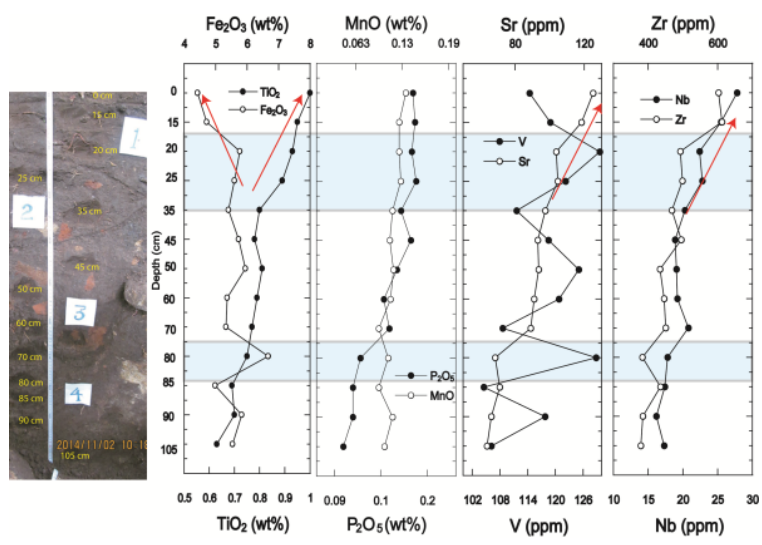

Fig. 5. Elemental variation of the soil profile in the Nikasala Nuwara archaeological site Fe Mn $\mathrm{Sr}, \mathrm{Zr}, \mathrm{Ti}, \mathrm{P}, \mathrm{V}$ and $\mathrm{Nb}$ with the corresponding soil profile and the layer numbers.
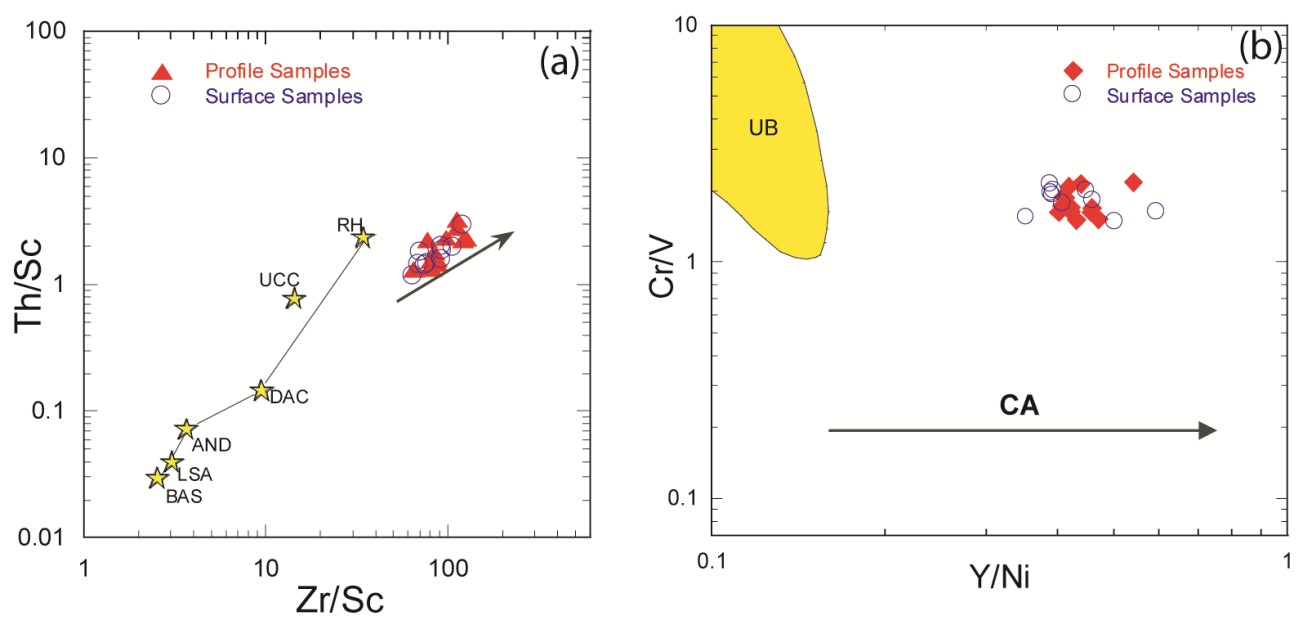

Fig. 6. (a) $\mathrm{Zr} / \mathrm{Sc}-\mathrm{Th} / \mathrm{Sc}$ ratio plots (McLennan et al., 1993) for surface and profile soils from Nikasala Nuwara archaeological site, showing zircon concentration (arrow). (b) $\mathrm{Cr} / \mathrm{V}-\mathrm{Y} / \mathrm{Ni}$ plots (McLennan et al., 1993) surface and profile soils from Nikasala Nuwara archaeological site, showing the lack of ultrabasic sources. 
Table 1. Showing the mean, minimum and maximum and bulk values of elemental values of the surface and soil profile at the Nikasala Nuwara archaeological site. UCC values of Taylor and McLennan (1985). The Major elements are as oxide wt\% and trace elements are in ppm.

\begin{tabular}{|c|c|c|c|c|c|c|c|c|c|c|c|c|c|c|c|c|c|c|c|c|c|c|c|}
\hline Sample & As & $\mathrm{Pb}$ & $\mathrm{Zn}$ & $\mathrm{Cu}$ & $\mathrm{Ni}$ & $\mathrm{Cr}$ & $\mathrm{V}$ & $\mathrm{Sr}$ & $\mathrm{Y}$ & $\mathrm{Nb}$ & $\mathrm{Zr}$ & Th & $\mathrm{Sc}$ & TS & $\mathrm{F}$ & $\mathrm{Br}$ & I & $\mathrm{Cl}$ & $\mathrm{TiO}_{2}$ & $\mathrm{Fe}_{2} \mathrm{O}_{3}$ & $\mathrm{MnO}$ & $\mathrm{CaO}$ & $\mathrm{P}_{2} \mathrm{O}_{5}$ \\
\hline \multicolumn{24}{|c|}{ Surface Samples } \\
\hline NSNF 1 & F.1. & 33.3 & 80.3 & 35.2 & 14 & 58.8 & 152 & 82.8 & 29.1 & 20 & 460 & 11.6 & 6.5 & 427 & 15 & 4 & 14.5 & nd & 0.79 & 8.27 & 0.23 & 0.78 & 0.166 \\
\hline NSN F 2 & 4.9 & 22.9 & 68.2 & 41.5 & 19 & 58 & 115 & 80.1 & 27.6 & 21 & 405 & 7.7 & 5.4 & 421 & 89 & 3.4 & 23.4 & nd & 0.80 & 6.05 & 0.12 & 0.76 & 0.135 \\
\hline NSN F 3 & 5.9 & 24.7 & 67.2 & 34.2 & 14 & 54.3 & 121 & 92.9 & 27.5 & 20 & 458 & 8.5 & 4.3 & 449 & 56 & 4.5 & 22.5 & nd & 0.85 & 5.79 & 0.14 & 0.84 & 0.14 \\
\hline NSN F 4 & 5.3 & 21.4 & 65.3 & 29.2 & 14 & 42.0 & 108 & 86.9 & 27.1 & 20 & 436 & 9.1 & 6.3 & 412 & 104 & 3.8 & 24.6 & nd & 0.79 & 5.19 & 0.12 & 0.77 & 0.13 \\
\hline NSN F 5 & 4.9 & 24.2 & 69.3 & 32.2 & 15 & 41.6 & 106 & 92.6 & 27.6 & 22 & 461 & 8.8 & 6.0 & 430 & 103 & 4.2 & 23.9 & nd & 0.84 & 5.07 & 0.13 & 0.79 & 0.14 \\
\hline NSN F 6 & 5.3 & 23.5 & 70.1 & 33.3 & 15 & 45.1 & 115 & 90.9 & 29.2 & 22 & 498 & 8.5 & 5.4 & 433 & 89 & 4.7 & 19.5 & nd & 0.79 & 5.30 & 0.13 & 0.79 & 0.12 \\
\hline NSN F 7 & 4.9 & 23.2 & 64.3 & 32.3 & 16 & 69.5 & 117 & 88.2 & 26.2 & 19 & 457 & 8.3 & 7.1 & 431 & 352 & 4.1 & 24.4 & nd & 0.80 & 5.55 & 0.12 & 0.77 & 0.14 \\
\hline NSN F 8 & 5.1 & 23.5 & 66.0 & 38.5 & 18 & 39.3 & 112 & 89.5 & 27.7 & 21 & 471 & 11.5 & 3.9 & 410 & 161 & 4.3 & 24.9 & nd & 0.79 & 5.03 & 0.11 & 0.78 & 0.12 \\
\hline NSN F 9 & 5.3 & 24.4 & 66.4 & 32.1 & 16 & 41.6 & 102 & 91.5 & 28.4 & 21 & 480 & 10.3 & 5.2 & 413 & nd & 4.2 & 20.1 & nd & 0.80 & 4.89 & 0.12 & 0.78 & 0.12 \\
\hline NSN F 10 & 6.6 & 28.8 & 89.8 & 38.2 & 16 & 58.4 & 127 & 96.7 & 29.6 & 20 & 503 & 9.9 & 5.4 & 444 & nd & 4.9 & 20.7 & nd & 0.80 & 6.22 & 0.15 & 0.83 & 0.15 \\
\hline Mean & 5.4 & 25.0 & 70.7 & 34.7 & 16 & 50.9 & 118 & 89.2 & 28.0 & 21 & 463 & 9.4 & 5.6 & 427 & 121 & 4.2 & 21.9 & & 0.81 & 5.74 & \begin{tabular}{|l|}
0.14 \\
\end{tabular} & 0.79 & 0.14 \\
\hline Minimum & 4.9 & 21.4 & 64.3 & 29.2 & 14 & 39.3 & 102 & 80.1 & 26.2 & 19 & 405 & 7.7 & 3.9 & 410 & 15 & 3.4 & 14.5 & & 0.79 & 4.89 & 0.11 & 0.76 & 0.12 \\
\hline Maximum & 6.6 & 33.3 & 89.8 & 41.5 & 19 & 69.5 & 152 & 96.7 & 29.6 & 22 & 503 & 11.6 & 7.1 & 449 & 352 & 4.9 & 24.9 & & 0.85 & 8.27 & 0.23 & 0.84 & 0.17 \\
\hline
\end{tabular}

\begin{tabular}{|c|c|c|c|c|c|c|c|c|c|c|c|c|c|c|c|c|c|c|c|c|c|c|c|}
\hline \multicolumn{24}{|c|}{ Profile Samples } \\
\hline NSN 1 & 5.1 & 26.3 & 72.3 & 27.3 & 15 & 47.8 & 114 & 125.1 & 30.4 & 28 & 603 & 11.0 & 4.8 & 596 & 74 & 5.1 & 23.7 & nd & 1.00 & 4.43 & 0.16 & 1.08 & 0.13 \\
\hline NSN 2 & 5.4 & 25.4 & 76.2 & 32.2 & 17 & 49.0 & 119 & 118.5 & 30.9 & 26 & 613 & 13.1 & 7.3 & 518 & 58 & 5.2 & 28.9 & nd & 0.95 & 4.72 & 0.16 & 0.95 & 0.12 \\
\hline NSN 3 & 5.0 & 26.0 & 80.0 & 39.9 & 18 & 54.4 & 130 & 103.9 & 31.1 & 22 & 493 & 9.0 & 5.7 & 492 & 74 & 4.8 & 23.9 & nd & 0.93 & 5.77 & 0.16 & 0.87 & 0.12 \\
\hline NSN 4 & 5.4 & 26.1 & 77.8 & 38.4 & 19 & 49.6 & 122 & 104.7 & 31.7 & 23 & 499 & 8.5 & 6.3 & 476 & 41 & 5.2 & 24.4 & nd & 0.89 & 5.60 & 0.16 & 0.86 & 0.13 \\
\hline NSN 5 & 5.6 & 24.6 & 75.0 & 36.4 & 18 & 44.8 & 112 & 97.5 & 29.4 & 20 & 468 & 9.1 & 5.8 & 436 & 58 & 4.5 & 17.8 & nd & 0.80 & 5.41 & 0.15 & 0.82 & 0.11 \\
\hline NSN 6 & 5.9 & 25.7 & 86.0 & 38.3 & 20 & 51.0 & 119 & 93.1 & 30.7 & 19 & 496 & 8.2 & 6.1 & 443 & 89 & 4.0 & 24.1 & 158 & 0.78 & 5.73 & 0.16 & 0.86 & 0.11 \\
\hline NSN 7 & 4.7 & 25.0 & 78.0 & 38.5 & 19 & 58.8 & 125 & 93.8 & 29.3 & 19 & 434 & 8.8 & 6.7 & 426 & nd & 3.7 & 19.5 & nd & 0.81 & 5.95 & 0.15 & 0.86 & 0.12 \\
\hline NSN 8 & 5.1 & 24.0 & 73.1 & 38.2 & 18 & 55.2 & 121 & 91.0 & 28.4 & 19 & 446 & 7.5 & 5.1 & 417 & 120 & 3.5 & 23.8 & nd & 0.79 & 5.37 & 0.13 & 0.86 & 0.11 \\
\hline NSN 9 & 4.8 & 24.2 & 69.5 & 32.9 & 17 & 45.7 & 109 & 89.1 & 28.5 & 21 & 451 & 11.2 & 4.0 & 387 & 183 & 3.2 & 21.4 & nd & 0.77 & 5.33 & 0.14 & 0.80 & 0.10 \\
\hline NSN 10 & 4.3 & 24.5 & 58.6 & 33.0 & 13 & 69.7 & 129 & 68.6 & 29.0 & 18 & 384 & 11.1 & 3.4 & 382 & 200 & 2.7 & 17.6 & 354 & 0.75 & 6.67 & 0.11 & 0.77 & 0.11 \\
\hline NSN 11 & 4.7 & 22.7 & 56.5 & 29.7 & 13 & 42.8 & 105 & 71.2 & 24.5 & 17 & 436 & 8.1 & 3.6 & 363 & 120 & 2.4 & 18.7 & nd & 0.69 & 4.99 & 0.10 & 0.74 & 0.10 \\
\hline NSN 12 & 5.2 & 21.7 & 61.4 & 34.5 & 15 & 54.0 & 118 & 66.3 & 24.8 & 16 & 385 & 11.3 & 5.0 & 372 & 17 & 2.7 & 23.0 & nd & 0.70 & 5.83 & 0.10 & 0.74 & 0.11 \\
\hline NSN 13 & 4.5 & 22.4 & 59.7 & 23.1 & 12 & 46.5 & 106 & 63.9 & 25.8 & 17 & 379 & 9.1 & 3.9 & 355 & 183 & 2.1 & 20.7 & nd & 0.63 & 5.54 & 0.10 & 0.70 & 0.10 \\
\hline Mean & 5.1 & 24.5 & 71.1 & 34.0 & 16 & 51.5 & 117 & 91.3 & 28.8 & 20 & 468 & 9.7 & 5.2 & 436 & 101 & 3.8 & 22.1 & 256 & 0.81 & 5.49 & 0.14 & 0.84 & 0.11 \\
\hline Minimum & 4.3 & 21.7 & 56.5 & 23.1 & 12 & 42.8 & 105 & 63.9 & 24.5 & 16 & 379 & 7.5 & 3.4 & 355 & 17 & 2.1 & 17.6 & 158 & 0.63 & 4.43 & 0.10 & 0.70 & 0.10 \\
\hline Maximum & 5.9 & 26.3 & 86.0 & 39.9 & 20 & 69.7 & 130 & 125.1 & 31.7 & 28 & 613 & 13.1 & 7.3 & 596 & 200 & 5.2 & 28.9 & 354 & 1.00 & 6.67 & 0.16 & 1.08 & 0.13 \\
\hline $\mathrm{UCC}$ & 5 & 17 & 67 & 28 & 47 & 92 & 97 & 320 & 21 & 12 & 193 & 11 & 14 & & 557 & 1.6 & 1.4 & 0.037 & 0.64 & 5.04 & 0.1 & 3.59 & 0.15 \\
\hline
\end{tabular}

\section{Provenance Indicators}

The $\mathrm{Th} / \mathrm{Sc}$ ratio is commonly used to determine the source since it is a sensitive index of the bulk composition (Taylor and McLennan, 1985). The $\mathrm{Zr} / \mathrm{Sc}$ ratio serves as a proxy for identifying heavy mineral concentrations, because it is highly sensitive to accumulation of zircon. The surface samples and the profile samples are overlapping each other clearly indicating the same source. The average of $\mathrm{Zr} / \mathrm{Sc}$ is 86.1 and 93.1 for surface samples and the profile samples; respectively. This suggests that the soils are highly enriched in $\mathrm{Zr}$ indicating high heavy mineral signature (Fig. 6a). In the Figure 6a the stars are average basalt (BAS), andesite (AND), dacite (DAC) and rhyolite (RHY), as plotted by Roser and Korsch (1999); stars (I) average I-type granite, (S) average Stype granite (Whalen et al., 1987). The $\mathrm{Cr} / \mathrm{V}$ $\mathrm{Y} / \mathrm{Ni}$ also surface samples and the profile samples are overlapping each other (Fig. 6b). In Figure $4 \mathrm{~b}$ the UB: ultrabasic; field of sands derived from ultrabasic rocks in the Hino River, South West Japan (Ortiz and Roser, 2006); CA: typical calc-alkaline trend. The soils of this site do not show any ultrabasic compositions and the samples show a slight calk alkaline trend.

\section{CONCLUSIONS}

The increased $\mathrm{As}, \mathrm{Zn}, \mathrm{Pb}, \mathrm{Cu}, \mathrm{Ni}$ and $\mathrm{Cr}$ concentrations towards the top part of the profile may indicates gradual increase in human activities in the area and the concentrations of $\mathrm{V}, \mathrm{Nb}, \mathrm{Sr}, \mathrm{Zr}$, Th and $\mathrm{Sc}$ may related to gradually increase in weathering activities and 
grain size variation. The high peaks in the profile for $\mathrm{As}, \mathrm{Pb}, \mathrm{Zn}, \mathrm{Cu}, \mathrm{Ni}, \mathrm{Cr}, \mathrm{Fe}$ and $\mathrm{V}$ relate to slag, furnace (paddy husk, sand and clay with termite clay) and $\mathrm{Fe}$ and $\mathrm{Cu}$ smelting during this period.

The use of geochemical data is a more accurate method to prove archeological evidences. Chemical data of the present study

\section{ACKNOWLEDGEMENTS}

Prof. Gamini Adikari, former Director General Central Cultural Fund (CCF) and Mr H.A.C. Gayan, Research officer of CCF. Mr. Janith Nishantha and Mr. Dinesh Marasinghe of Rajarata University of Sri Lanka who helped in sampling and Mr. Thiwanka Siriwardena for the suggestions and editing assistance.

\section{REFERENCES}

Aston, M., Martin, M. and Jackson A. (1998) The use of heavy metal soil analysis for archaeological surveying. Chemosphere, 37(3): 456-477.

Bintliff, J.L., Gaffney, C., Waters, A., Davies, B. and Snodgrass A. (1990) Trace metal accumulation in soils on and around ancient settlements in Greece. Man's role in the shaping of the eastern Mediterranean landscape, Balkema, Rotterdam.

Conservation of Soil Resources (2016) of the Kapiriggama Small Tank Cascade System, IUCN, Sri Lanka Country Office, pp 52.

Dalai, B. and Ishiga H. (2012) Geochemical evaluation of present-day Tuul River sediments, Ulaanbaatar basin. Mongolia. Environmental Monitoring and Assessment, DOI 10.1007/s10661-012-2757-z

Deraniyagala, S.U. (1992) The Prehistory of Sri Lanka; An Ecological Perspective, Colombo, Archaeological Survey Department.

Emadodin, I. (2011) Soil and sediment chronology as a tool to study long-term natural and humaninduced land degradation: An overview. Soil Science, 6(1): 12-18.

Entwistle, J.A., Abrahams, P.W. and Dodgshon, R.A. (1998) Multi-element analysis of soils from Scottish historical sites. Interpreting land-use history through the physical and geochemical confirms different anthropogenic activities that have taken place in the area. Therefore, eventhough the Nikasalanuwara area is presently a Buddhist monastery site, it may have been a residential area in the past. However, for clear understanding of the historical evolution of the area, more samples are needed to be analyzed geochemically.

analysis of soil. Journal of Archaeological Science, 25: 53-68.

Hodder, I. and Hutson, S. (2003) Reading the Past: Current Approaches to Interpretation in Archaeology. Cambridge University Press, Cambridge, UK.

Holliday, T.V. and Gartner, W.G. (2007) Methods of soil $\mathrm{P}$ analysis in archaeology, Journal of Archaeological Science 34: 301-333.

Hughes, R.H. and Smith, R.L. (1993) Archaeology, geology, and geochemistry in obsidian provenance studies, Geological Society of America, Special Paper, 283: 1-20.

Linderholm, J. (2007) Soil chemistry surveying: A path to a deeper understanding of prehistoric sites and societies in Sweden. Geoarchaeology, 22(4): 417-438.

McLennan, S.M., Hemming, S., McDaniel, D.K. and Hanson, G.N. (1993) Geochemical approaches to sedimentation, provenance and tectonics. Geological Society of America, Special Paper 284: 21-40.

Mendis, T., Harshajith N. and Jayasekara, I. (2019) Anderawewa megalithic burial excavation, Settlement archaeology of middle Daduru oya basin, Rajarata University of Sri Lanka, 374.

Middleton, W.D. and Price, T.D. (1996) Identification of activity areas by multi-element characterization of sediments from modern and archaeological house floors using inductively coupled plasma-atomic emission spectroscopy. Journal of Archaeological Science, 23: 673-687.

Ogasawara, M. (1987) Trace element analysis of rock samples by X-ray fluorescence spectrometry, using $\mathrm{Rh}$ anode tube. Bulletin of the Geological Survey of Japan, 38(2): 57-68. 
Ortiz, E. and Roser, B.P. (2006) Major and trace element provenance signatures in streamsediments from the Kando river, San'in district, southwest Japan. Island Arc, 15: 223-238.

Roser, B.P. and Korsch, R.J. (1999) Geochemical characterization, evolution and source of a Mesozoic accretionary wedge: the Torlesse terrane. New Zealand. Geological Magazine, 136: 493-512.

Schlezinger, D.R. and Howes, B.L. (2000) Organic phosphorus and elemental ratios as indicators of prehistoric human occupation. Journal of Archaeological Science, 27: 479-492.

Seneviratne, S. (1984) The Archaeology of the Megalithic - Black and Red Ware Complex in Sri Lanka, Ancient Ceylon, 5: 237-305.

Selivanova, M.N. and Ashley, G.M. (1998) Geological-Geochemical Approach to "Sourcing" of Prehistoric Chert Artifacts, Northwestern Alaska, Geoarchaeology, 13: 673-708.

Smejdaa, L., Hejcmana, M., Horaka, J. and Shai, I. (2017) Ancient settlement activities as important sources of nutrients $(\mathrm{P}, \mathrm{K}, \mathrm{S}, \mathrm{Zn}$ and $\mathrm{Cu})$ in Eastern Mediterranean ecosystems - The case of biblical Tel Burna, Israel, Catena, 156: 62-73.

Strimaitienėa, A.S., Selskienèb, A., Vaičiūnienèb J., Pakštasb, V. and Šmigelskasa, R. (2017) Tracing Archaeology through Geochemistry: an Example of a Disturbed Prehistoric Hilltop Settlement Site in South-Eastern Lithuania, Interdisciplinaria Archaeological Natural Sciences in Archaeology.

Taylor, S.R. and McLennan, S.M. (1985) The continental crust: its composition and evolution. Blackwell, Oxford, p 312.

Vranová V., Marfo T.D., Rejšek K. (2015) Soil scientific research methods used in archaeology promising soil biochemistry: a mini-review, Acta Universitatis Agriculturae et Silviculturae Mendelianae Brunensis, 65: 1417-1426.

Whalen, J.B., Currie K.L. and Chappell., B.W. (1987) A-type granites-geochemical characteristics, discrimination and petrogenesis. Contributions to Mineralogy and Petrology, 95: 407-419.

Wilson, C.A., Davidson, D.A. and Cresser, M.S. (2008) Multi-element soil analysis: an assessment of its potential as an aid to archaeological interpretation. Journal of Archaeological Science, 35: 412-424. 